Tér és Társadalom 24. évf. 2010/1. 187-188. p.

Tér és Társadalom

XXIV. évf. 2010

1: $187-188$

\title{
KÖNYVJELZÖ
}

\section{PAP NORBERT - KOBOLKA ISTVÁN (SZERK.): A NYUGAT-BALKÁN}

\author{
(MK Katonai Biztonsági Hivatal Tudományos Tanácsa, \\ Budapest, 2009. 238 o)
}

\section{KRISZTIÁN BÉLA}

A földrajzi és biztonsági paradigma Balkán vonatkozásai már korábban körvonalazódtak, de az európaiak számára talán a Balkán az, ami az ókortól kezdve különböző történelmi korszakokon átívelö módon állandó figyelem tárgya. Ebben gyakran nem az objektív fogalmak, hanem az ideologikus csúsztatások nyomán megjelenők alkotnak vegyes érzelmeket kiváltó megközelítéseket, vagy ennek következtében téves útra fordulást.

A földrajz és a biztonság rendezỏ elvének ötvözetét az alkotó szerkesztők Kobolka István és Pap Norbert - mindvégig érvényesítették. A földrajzilag ugyan jól meghatározható félsziget rendkívül változatos népessége, az archaikus és modern formák keveredése, a stratégiai jelentőségtől a mellőzött formációig történő megítélés egyaránt sajátja a feldolgozásoknak. Biztonsági szempontokból is sok feltételezés tárgya a Balkán - a túlzottan is a szokásokhoz és egy elfogadott ,rendhez” alkalmazkodó nyugati berendezkedések nehezen birkóznak meg egy aktív, a változtatás állandóságában élő, a természeti környezettöl is befolyásolt nagyfokú alkalmazkodási rugalmasságot kiváltó, a népesség eredetre, teljesítményképességre bizonyító folyamatával. Az MK Katonai Biztonsági Hivatala tudományos tevékenységének újabb eseménye az aktualitáson túlmutató Nyugat-Balkán kötet megjelentetése. A színvonalas kiadvány a HM Térképészeti NKFt. nyomdájában készuilt. A számos térkép, jól szerkesztett, adatsürü táblázat gazdagítja a sokoldalú feldolgozást.

A kötet tanulmányai a történetiséggel, a változásokkal és 2008-cal befejezett adatsokasággal foglalkoznak a balkáni terület-együttessel. Az arányosan szerkesztett tanulmányok - Hajdú Zoltán: A Nyugat-Balkán: történeti földrajzi bevezetés; Háry Szabolcs: Katonai képességek a Nyugat-Balkánon; Hóvári János: A Nyugat-Balkán határai és települési, regionális sajátosságai; Kovács János: A Nyugat-Balkán természeti kömyezete; M. Császár Zsuzsa: A Nyugat-Balkán oktatási rendszerei; Pap Norbert: Magyarország kapcsolatrendszere a Balkán államaival; és ugyanő: Gazdasági tevékenységek a Nyugat-Balkánon; Reményi Péter: Az európai perspektívák vonzásában és a hagyományok szorításában: a volt jugoszláv térség. Dél-kelet Európa és a Nyugat-Balkán a nemzetközi kapcsolatok rendszerében (1991-2008); 
Varga Gábor: A Nyugat-Balkán természeti környezete; Végh Andor: A NyugatBalkán etnikai képe - átfogó, de a sajátos vonásokat is megjelenítik a kötetben. A munkából a Balkánt a korábbinál jóval szélesebben és mélyen differenciált egységként ismerjük meg, a tudomány, a földrajz, a katonai erők, a termelő ember természetes körét és oktatását is átfogva, ezzel a Balkánt az európai rendszerre artikulálva. Ez a megközelítés - a KBH tudományos elveiből adódóan - azért fontos, mert túllép a politikai és társadalmi makroszintek abszolutizálásán a mikroszintek kölcsönhatásai kibontása felé. Ezzel módot nyújt az európai redisztribúció makroszinteket preferáló mechanizmusainak átértékelésére is. Bár néhány szerző a jelenlegi állapotokat a potenciális bizonytalanság további éltetỏjének tartja, a kötet számunkra azt igazolja, hogy a rövid távú szemlélet és sikerigény meghaladásával fel kell oldani a restrikciós spirált egy hosszú távra orientált Balkán szemlélet segítségével bővülő spirállá, amelyhez a szükséges kiindulópontot éppenséggel a balkáni országok földrajzi adottságai és emberi erőforrásainak hasznosítása adja.

Jelenünkben új lendülettel történik a regionalitások és etnikai alternatívák újraértékelése, módszertani nóvumok sokaságával találkozunk, amelyek a földrajz- és biztonságtudomány, a tudástársadalom nem csupán a Balkánnal kapcsolatos felületes vélemények, hanem a Balkánnal kapcsolatos változó megítélések reflexív felfogásának eszközei. A kötet ebben a szellemben ad sokirányú és jól hasznosítható ismereteket. 